\title{
EVALUASI KEBIJAKAN ASESMEN TERPADU DALAM UPAYA REHABILITASI PENYALAHGUNA NARKOTIKA DI KOTA DEPOK
}

\author{
Ela Bestia dan Palupi Lindiasari Samputra
}

Sekolah Kajian Stratejik dan Global, Universitas Indonesia

Email: ela.bestia@gmail.com dan palupi.ls@ui.ac.id

\section{Abstract}

The purpose of this study is to evaluate the existing TAT policies in the Depok area. Researchers used a policy evaluation theory with mapping obstacles in program implementation. The research method used a qualitative approach with descriptive analysis techniques. The results showed that the implementation of TAT in Depok City was not yet practical because it had not reached the target. Apart from technical constraints, the performance of TAT for narcotics abusers is not, however, an obligation for law enforcement officials. For this reason, the TAT policy needs to include statutory regulations that bind all law enforcement officials. So that rehabilitation efforts for narcotics abusers can run effectively.

Keywords: Policy Evaluation, Integrated Assesment, Narcotics

\begin{abstract}
Abstrak
Tujuan dari penelitian ini adalah untuk mengevaluasi kebijakan TAT yang ada di wilayah Depok. Peneliti menggunakan teori evaluasi kebijakan proses retrospektif, dengan teknik hambatan dalam implementasi program. Metode penelitian menggunakan pendekatan kualitatif dengan teknik analisis deskriptif. Hasil penelitian menunjukan pelaksanaan TAT di Kota Depok belum efektif karena belum mencapai target. Selain kendala teknis, pelaksanaan TAT bagi penyalahguna narkotika belum merupakan suatu kewajiban bagi aparat penegak hukum. Untuk itu kebijakan TAT perlu dimasukan ke dalam peraturan per undang-undangan yang mengikat semua aparat penegak hukum. Sehingga upaya rehabilitasi bagi penyalahguna narkotika dapat berjalan efektif.
\end{abstract}

Kata kunci: Evaluasi Kebijakan, Asesmen Terpadu, Narkotika

Coresponden Author

Email: ela.bestia@gmail.com Artikel dengan akses terbuka dibawah lisensi

\section{Pendahuluan}

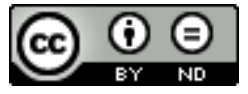

Pada tahun 2015, Presiden Joko Widodo mengeluarkan status bahwa Indonesia kini dalam kondisi darurat narkoba, setiap harinya 40-50 orang meninggal dunia karena narkoba. Pada saat itu kampanye tentang Indonesia Darurat Narkoba selalu digaungkan, namun apakah pesan-pesan tersebut hanya sekedar slogan, apakah ada arah kebijakan 
yang jelas dan berkesinambungan untuk mengatasi status darurat narkoba tersebut. Berdasarkan laporan BNN di sepanjang tahun 2019 tercatat sebanyak 30 orang meninggal dunia setiap harinya di Indonesia akibat narkotika, angka prevalensi penyalahguna narkotika pada tahun 2019 mencapai 1,8\% yang artinya terdapat 3,41 juta jiwa penyalahguna narkotika (Pandjaitan, 2020).

Dasar hukum yang digunakan dalam rangka penanganan penyalahgunaan narkotika adalah UU No. 35 tahun 2009. Pemerintah menyadari bahwa dalam rangka menanggulangi kejahatan narkotika, tidak cukup hanya dengan hukuman penjara, namun dibutuhkan upaya pengobatan kecanduannya yaitu melalui rehabilitasi. Upaya represif yang diarahkan kepada pecandu atau penyalahguna tanpa disertai upaya rehabilitasi akan membuat potensi residivisme semakin tinggi (Iskandar \& IK, 2019). Terdapat perubahan paradigma dalam penanganan penyalahgunaan narkotika di Indonesia, salah satunya mewajibkan penyalahguna dan korban penyalahgunaan narkotika untuk menjalankan rehabilitasi berupa medis dan sosial. Rehabilitasi medis merupakan langkah pengobatan untuk melepaskan pecandu atas adiksi yang dialaminya, disisi lain, rehabilitasi sosial dilakukan agar pecandu memiliki kesiapan sosial, sikap mental yang tangguh untuk mengatasi kendala dalam lingkungan agar ia dapat lebih siap saat reintegrasi di dalam masyarakat.

Ketentuan Pidana dalam Undang-Undang Narkotika Nomor 35 Tahun 2009 Pasal 127 disebutkan bahwa dalam memutus perkara penyalahgunaan narkoba, terdapat pasal yang perlu diperhatikan, yaitu ketentuan dalam Pasal 54, 55 dan 103. Pasal yang berkaitan menerangkan bahwa masa menjalani program rehabilitasi akan termasuk dalam masa hukuman, selain itu, hakim tidak hanya terbatas pada pemberian hukuman berupa pemenjaraan, namun terdapat pilihan hukuman rehabilitasi bagi pecandu narkotika (Iskandar \& IK, 2019).

Untuk memenuhi amanat Undang-undang Narkotika No.35 tahun 2009, pada tahun 2014 pimpinan tujuh lembaga yang terdiri dari Kepala BNN RI, Ketua Mahkamah Agung, Menkumham, Jaksa Agung, Kapolri, Menkes, Mensos menandatangani Kebijakan Penanganan Pecandu Narkotika dan Korban Penyalahgunaan Narkotika ke dalam Lembaga Rehabilitasi yang tertuang dalam Peraturan Bersama No. PERBER/01/III/2014/BNN (Hidayat \& Heryanto, 2019).

Terbentuknya Peraturan Bersama tersebut, menghasilkan terobosan baru yaitu dibentuknya Tim Asesmen Terpadu (TAT) yang berkedudukan di tingkat Pusat, Provinsi, Kabupaten/Kota. BNN yang berperan sebagai koordinator pelaksanaan P4GN bertugas membentuk tim TAT baik di level pusat maupun daerah. Dari unsur penegakan hukum, terdapat kerjasama antara BNN, Kepolisian, Kejaksaan serta Kemenkumham. Tim hukum TAT memiliki peran menganalisis jejaring narkotika dan berkomunikasi dengan penyidik perkara. Pada konteks rehabilitasi, terdapat tim yang terdiri dari dokter, dan psikolog. Mereka akan merekomendasikan terkait strategi penanganan yang tepat terkait rehabilitasi medis dan sosial pada pecandu tersebut (Afrizal \& Anggunsuri, 2019). Rekomendasi yang dikeluarkan tim TAT tersebut dijadikan dasar dalam hal membuktikan apakah seseorang masuk dalam kelompok pengedar yang akan 
dilanjutkan pada proses hukum lebih tinggi atau hanya berperan sebagai pecandu yang dikenakan kewajiban rehabilitasi.

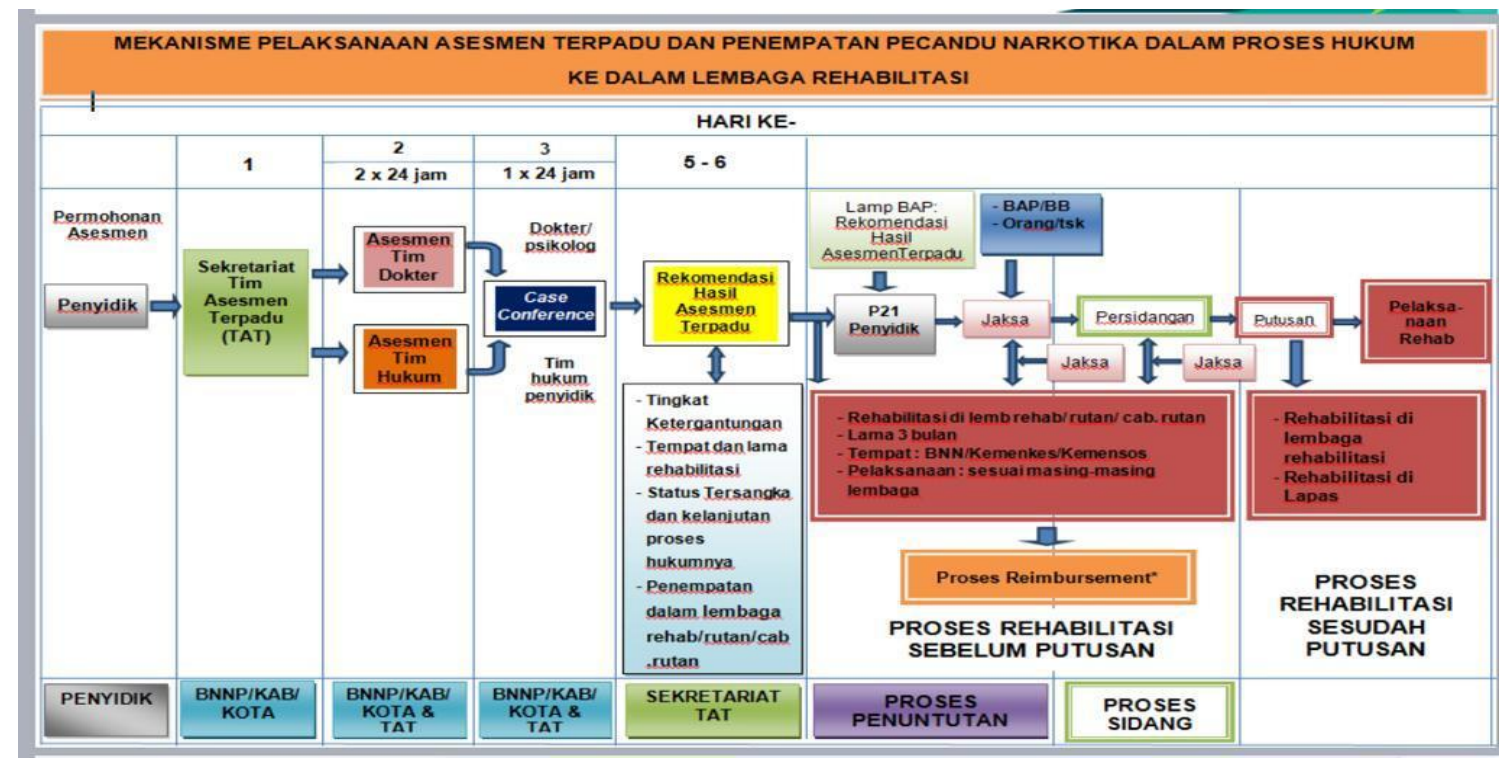

Gambar 1

Mekanisme Pelaksanaan Asesmen Terpadu dan Penempatan Pecandu Narkotika dalam Proses Hukum ke dalam Lembaga Rehabilitasi

(Sumber : BNN RI)

Badan Narkotika Nasional Kota Depok merupakan pelaku kebijakan TAT di tingkat kabupaten/kota. BNNK Depok telah melaksanakan kegiatan Tim Asesmen Terpadu (TAT) di Kota Depok sejak tahun 2016. Namun di tahun 2020 terjadi penurunan pelaksanaan TAT di Kota Depok. Tapi disisi lain narapidana kasus narkotika yang berada di Rutan Kelas 1 Depok mengalami peningkatan hingga menyebabkan rutan over kapasitas.

Berdasarkan data Warga Binaan Permasyarakatan (WBP) Rutan Kelas 1 Depok per Juni 2020, terdapat Jumlah WBP jenis pidana Narkotika sebanyak 1086 orang, dimana 9 diantara WBP tersebut dikenai pasal 127 yaitu pasal tentang penyalahguna narkotika. Hal ini mengindikasikan bahwa terdapat sejumlah penanganan kasus penyalahguna narkotika di Depok tanpa melibatkan Tim Asesmen Terpadu. Sehingga penulis merasa perlu untuk melakukan evaluasi terhadap kebijakan dan program Tim Asesmen Terpadu dengan menggunakan teori analisis kebijakan.

\section{Tabel 1}

\section{Data Warga Binaan Rutan Kelas 1 Depok}

\begin{tabular}{lcc}
\multicolumn{3}{l}{ Jumlah WBP Jenis Pidana Narkotika } \\
\hline Jumlah Tahanan & 128 & orang \\
Jumlah narapidana & 958 & orang \\
Jumlah Total & 1086 & orang \\
\hline
\end{tabular}

(Sumber : Rutan Kelas 1 Depok) 
Tabel 2

Data WBP Kasus Narkotika berdasarkan Pasal Pidana

Jumlah WBP Jenis Pidana Narkotika

\begin{tabular}{llll}
\hline No & Pasal & Jumlah & WBP \\
\hline 1 & 127 & 9 & orang \\
2 & 112 & 286 & orang \\
3 & 111 & 77 & orang \\
4 & 114 & 709 & orang \\
5 & 129 & 2 & orang \\
6 & 132 & 3 & orang \\
\hline Jumlah Total & 1086 & orang \\
\hline
\end{tabular}

(Sumber : Rutan Kelas 1 Depok)

Lester dan Steward dalam (Kawengian \& Rares, 2015) menjelaskan bahwa pada evaluasi kebijakan terutama dalam proses implementasi perlu dilakukan untuk menemukan pada titik mana kebijakan tidak berjalan. Mengutip Lester \& Stewart dalam (Agustino, 2016) evaluasi kebijakan dilakukan untuk menilai jalannya kebijakan yang telah dilaksanakan, baik dari segi keberhasilan maupun kekurangan berdasarkan indikator atau standar yang telah dibuat.

Dunn mengembangkan tiga pendekatan dalam evaluasi kebijakan yang terdiri dari: evaluasi semu, evaluasi formal, dan evalusi keputusan teoritis. Dalam evaluasi formal tujuan programnya diumumkan secara formal, menggunakan metode deskriptif untuk menginformasikan hasil kebijakan. Dalam pendekatan formal ini, penulis menggunakan tipe evaluasi proses retrospektif dimana pemantauan serta evaluasi program dilakukan paska sebuah program dilaksanakan dalam rentang waktu yang ditentukan. Penilai kebijakan akan melihat hambatan dari implementasi kebijakan dan program yang telah dilaksanakan tersebut. Teknik yang digunakan dalam evaluasi program ini adalah melalui pemetaan hambatan sehingga dapat diukur keluaran beserta dampak atas kebijakan atau program yang dilaksanakan (Dunn, 2003).

Penelitian sebelumnya menemukan bahwa: 1) Dalam pelaksanaan TAT terdapat ketidaksamaan persepsi antara aparat yang berwenang di bidang hukum dalam penanganan tersangka penyalahguna narkotika, kekuatan hukum yang mengatur mengenai TAT dinilai masih belum cukup, berserta minimnya anggaran dalam pelaksanaan TAT tersebut (Hidayat \& Heryanto, 2019); 2) Diperlukan koordinasi yang terpadu antara aparat penegak hukum dengan pihak lainnya. Diperlukan kesamaan persepsi dari penyidik, penuntut umum, dan BNN bahwa pemidanaan tidak menjadi satu-satunya cara untuk menimbulkan penjeraan, namun pecandu perlu menjalani program rehabilitasi medis dan sosial (Afrizal \& Anggunsuri, 2019), 3) Penelitian TAT di Jakarta Selatan menyebutkan bahwa terdapat sejumlah hal yang mempengaruhi program TAT, yaitu sosialisasi, pemahaman, sasaran program, dan hasil akhir yang ingin dicapai serta pentingnya koordinasi yang terpadu antara pihak yang terlibat 
(Supratman, Nugroho, \& Wijayanti, 2020), 4) Tujuan dari asesmen terpadu sangat bagus namun, kurang efektif apabila IPWL (Institusi Penerima Wajib Lapor) atau Lembaga Rehabilitasi Milik Pemerintah belum siap melaksanakan program rehabilitasi bagi pecandu narkotika (Huda, Saefuddin, Gumira, \& Sumarji, 2020).

Keterbaruan penelitian ini adalah mengevaluasi implementasi kebijakan Tim Asesmen Terpadu menggunakan teori evaluasi kebijakan melalui pemetaan hambatan khususnya untuk wilayah Depok. Dari hasil temuan akan dibandingkan dengan penelitian yang sudah pernah ada.

Rumusan masalah dalam penelitian ini adalah bagaimana mekanisme dan evaluasi pelaksanaan asesmen terpadu yang telah dilakukan di wilayah Depok dilihat dari ketepatan sasaran dan kendala-kendala yang dihadapi.

Tujuan penelitian ini untuk memberikan gambaran tentang mekanisme pelaksanaan asesmen terpadu dan hasil evaluasi pelaksanaan kebijakan TAT di wilayah Depok agar dapat memberi sumbangan saran dalam pelaksanaan program TAT ke depannya sehingga dapat berjalan lebih efektif. Secara umum penelitian ini diharapkan menjadi solusi dalam penanganan penyalahgunaan narkotika di Kota Depok melalui upaya rehabilitasi terhadap pecandu baik yang terbukti bersalah atau yang tidak terbukti bersalah melakukan tindak pidana narkotika.

\section{Metode Penelitian}

Penelitian ini menggunakan metode penelitian kualitatif, dengan teknik analisis deskriptif. Teori yang digunakan adalah teori analisis kebijakan dengan pendekatan evaluasi formal. Dalam pendekatan formal ini, penulis menggunakan tipe evaluasi proses retrospektif dengan teknik evaluasi pemetaan hambatan. Sedangkan kriteria evaluatif yang digunakan dalam penelitian ini adalah efektifitas, dimana efektifitas merupakan kesesuaian hasil dengan target yang ingin di capai (Dunn, 2003). Selain itu efektivitas juga dapat dilihat dari indikator berikut: ketepatan sasaran program, sosialisasi program, tujuan program, dan pemantauan program (Pertiwi \& Nurcahyanto, 2017).

Tahapan mekanisme pelaksanaan asesmen terpadu yang akan penulis evaluasi dimulai dari permohonan asesmen oleh penyidik, lalu diproses oleh sekretariat atau admin TAT, dilakukannya asesmen oleh tim medis dan tim hukum hingga dilaksanakannya case conference oleh seluruh tim TAT hingga dikeluarkannya hasil rekomendasi tim asesmen terpadu.

Data yang digunakan dalam penelitian diperoleh melalui sumber primer dan sekunder. Data primer didapat dengan melakukan wawancara, dan data sekunder didapat melalui analisis dokumen dan literatur. Adapun Informan yang akan di wawancara terdiri dari: Kepala BNNK Depok, Kasie Rehabilitasi BNNK Depok, penyidik sebagai tim hukum, dokter sebagai tim medis, petugas administrasi TAT. Setelah data terkumpul lalu diolah dan dianalis untuk mendapatkan jawaban akhir mengenai masalah yang diteliti. Dalam hal analisis data dilakukan proses penyederhanaan dan interpretasi data (Miles \& Huberman, 2007). Pengujian keabsahan 
data dilakukan melalui triangulasi sumber dengan membandingkan informasi yang didapat dari sumber yang berbeda.

\section{Hasil dan Pembahasan}

\section{Mekanisme Pelaksanaan Asesmen Terpadu}

Tahap pertama pelaksanaan asesmen terpadu yaitu penyidik terlebih dahulu mengajukan permohonan pelaksanaan TAT ke sekretariat TAT. Berdasarkan Surat Edaran No: SE/9/II/KA/HK.01.05/2020/BNN tentang Pelaksanaan Asesmen Terpadu TA 2020, pada poin 3d dinyatakan bahwa "pengajuan permohonan asesmen oleh penyidik kepada Tim Asesmen Terpadu paling lama 6 (enam) hari sejak dilakukan penangkapan".

Setelah pengajuan permohonan asesmen oleh penyidik masuk ke sekretariat TAT, petugas sekretariat (administrasi TAT) memproses berkas kemudian memberikan surat pemberitahuan untuk dilaksanakan assessmen kepada pimpinan di instansi masing-masing dari tim pelaksana.

Tim Asesmen melaksanakan proses penilaian atau asesmen dalam waktu maksimal 2x24 jam sejak diterimanya berkas permohonan dari penyidik. Pada hari ke-4 hasil asesmen dari masing-masing tim asesmen dibahas pada pertemuan pembahasan kasus (case conference) untuk menetapkan rekomendasi hasil TAT.

Selanjutnya dalam jangka waktu paling lama 6 (enam) hari setelah pengajuan permohonan asesmen, Tim Asesmen Terpadu memberikan rekomendasi hasil asesmen kepada penyidik untuk dilaporkan secara tertulis kepada pengadilan negeri setempat. Rekomendasi TAT yang ditandatangani oleh ketua TAT menerangkan peran tersangka/terdakwa dalam tindak pidana, penilaian terhadap level adiksi penyalahguna, rekomendasi tindak lanjut dari proses hukum yang harus dijalani, serta rekomendasi untuk jenis terapi, lokasi, dan waktu rehabilitasi (Muslikan \& Taufiq, 2019).

Anggota TAT untuk Wilayah Depok diusulkan oleh Kepala BNN Kota Depok dan di tetapkan berdasarkan Surat Keputusan Kepala BNN Provinsi Jawa Barat terdiri dari: 1) Ketua Tim TAT yang dijabat oleh Kepala BNNK Depok, 2) Tim Hukum yang terdiri dari perwakilan kejaksaan, kepolisian, dan BNNK Depok, 3) Tim Medis yang terdiri dari: Dokter Puskemas dan Dokter Klinik Pratama BNNK Depok, 4) Sekretariat yang terdiri dari admin dan verifikator BNNK Depok.

\section{Evaluasi Program Tim Asesmen Terpadu}

Berdasarkan hasil wawancara dari pelaksana kebijakan TAT dan studi dokumentasi didapat data hasil evaluasi proses retrospektif yang terangkum dalam tabel berikut : 
Tabel 3

Hasil Evaluasi Proses Retrospektif

\begin{tabular}{|c|c|}
\hline Evaluasi & Hasil \\
\hline Efektifitas & $\begin{array}{l}\text { Pelaksanaan TAT untuk wilayah hukum Depok pada tahun } \\
2020 \text { hanya } 1 \text { (satu) orang dari } 10 \text { (sepuluh) target yang } \\
\text { dianggarkan. } \\
\text { Menurut Kepala BNNK Depok, Pelaksanaan TAT di Kota } \\
\text { Depok masih belum efektif karena belum berjalan } \\
\text { maksimal. (Wawancara, 21 Desember 2020). }\end{array}$ \\
\hline $\begin{array}{l}\text { Pemetaan } \\
\text { Hambatan }\end{array}$ & $\begin{array}{l}\text { 1) Tahap Pengajuan Permohonan Asesmen } \\
\text { Kendala pada tahap pengajuan permohonan asesmen, } \\
\text { dimana waktu yang ditentukan maksimal } 6 \text { hari setelah } \\
\text { penangkapan tersangka dirasa kurang oleh penyidik, karena } \\
\text { masih harus melakukan pengembangan kasus (wawancara } \\
\text { penyidik, } 21 \text { Desember 2020). Selain itu pelaksanaan TAT } \\
\text { dianggap belum merupakan suatu kewajiban yang harus } \\
\text { dilakukan oleh aparat penegak hukum (Pandjaitan, 2020). } \\
\text { 2) Administrasi TAT } \\
\text { Tidak ada kendala dalam proses menindaklanjuti } \\
\text { permohonan TAT oleh penyidik (Wawancara Admin TAT, } \\
\text { 21 Desember 2020) } \\
\text { 3) Asesmen Medis } \\
\text { Tidak ada kendala dalam proses asesmen medis. Tim medis } \\
\text { dalam melakukan asesmen medis menggunakan standar } \\
\text { SEMA (Surat Edaran Mahkamah Agung) untuk menentukan } \\
\text { seorang tersangka layak untuk direhabilitasi (Wawancara } \\
\text { Tim Medis, } 21 \text { Desember 2020). } \\
\text { 4) Asesmen Hukum } \\
\text { Tidak ada kendala dalam proses asesmen hukum. Dalam } \\
\text { melakukan asesmen hukum, tim hukum meninjau ulang } \\
\text { terhadap asumsi yang ditetapkan penyidik terhadap } \\
\text { tersangka apakah sebagai pengedar atau penyalahguna. } \\
\text { (Wawancara Tim Hukum, 21 Desember 2020). } \\
\text { 5) Pelaksanaan case conference (pembahasan kasus) } \\
\text { Tidak ada kendala dalam pelaksanaan case conference. } \\
\text { Pelaksanaan case conference rata-rata hadir semua walaupun } \\
\text { ada beberapa yang diwakilkan (Wawancara Admin TAT, } 21 \\
\text { Desember 2020). } \\
\text { 6) Rekomendasi Hasil Tim Asesmen Terpadu } \\
\text { Hasil rekomendasi Tim Asesmen Terpadu Kota Depok yang } \\
\text { penulis teliti sudah sesuai prosedur dan sesuai tujuan dari } \\
\text { terbentuknya TAT yaitu menyarankan agar tersangka yang } \\
\text { merupakan pecandu narkotika dapat menjalani terapi } \\
\text { rehabilitasi. }\end{array}$ \\
\hline
\end{tabular}

\section{a. Efektivitas Program Tim Asesmen Terpadu}

BNN Kota Depok menjalankan program Tim Asesmen Terpadu (TAT) di Kota Depok sejak tahun 2016. Pada tahun 2018, jumlah tersangka yang di 
TAT tercatat sebanyak 10 (sepuluh) orang dengan target 10 (sepuluh) orang, tahun 2019 jumlah yang di TAT sebanyak 3 (tiga) orang (target 10 orang), tahun 2020 jumlah yang di TAT sebanyak 1 (satu) orang (target 10 orang).

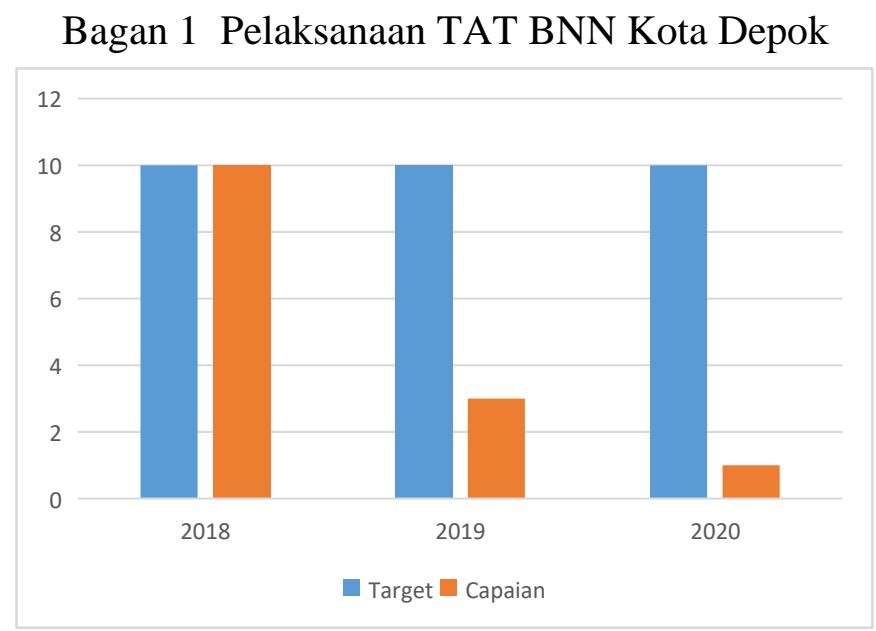

(Sumber : BNN Kota Depok 2020)

Berdasarkan bagan diatas dapat dilihat bahwa pada tahun 2020 pelaksanaan program asesmen terpadu belum mencapai target yang dianggarkan, pelaksanaan TAT untuk wilayah hukum Depok hanya 1 (satu) orang dari 10 (sepuluh) target yang dianggarkan. Ketika realisasi suatu program belum mencapai target dan tujuan yang diharapkan dapat dikatakan bahwa program asesmen terpadu tersebut belum berjalan efektif untuk mencapai tujuan dari program tersebut. Sedangkan SDM, Anggaran, dan informasi sudah cukup memadai. Namun menurut penulis rotasi yang begitu cepat dalam keanggotaan TAT dapat menjadi hambatan efektifitas pelaksanaan TAT itu sendiri.

Untuk indikator sasaran pelaksanaan program TAT sudah tepat yaitu tersangka yang tertangkap tangan dengan barang bukti dibawah ketentuan SEMA, merupakan seorang pecandu atau penyalahguna dengan hasil tes urin positif, tidak terlibat jaringan peredaran gelap narkotika, dan dijerat pasal 127 . Dalam hal sosialiasi program TAT masih tertuju pada sosialiasi antara pelaksana kebijakan dan belum ada program sosialisasi formal dari BNN Pusat mengenai prosedur baku TAT. Tujuan pelaksanaan program untuk menempatkan penyalahguna narkotika ke lembaga rehabilitasi belum tercapai karena pelaksanaannya masih belum berjalan maksimal. Dalam hal pemantauan terhadap tersangka yang telah menjalankan TAT belum pernah dilakukan oleh BNNK Depok karena tugas BNN hanya memberikan rekomendasi hasil TAT, mengenai tindak lanjut proses hukum ada pada penyidik dan kejaksaan, sedangkan keputusan akhir ada ditangan hakim. Berdasarkan hasil wawancara dengan Kasie Rehabilitasi BNNK Depok "memang kelemahan kita selama ini tidak memfollow up hasil TAT kepada penyidik yang menangani kasus, sehingga 
kita tidak mengetahui apakah orang yang kita rekomendasikan untuk rehabilitasi, apakah benar sudah menjalankan rehabilitasi. Namun untuk kedepannya sudah ada arahan dari BNN Pusat untuk menindaklanjuti hasil TAT” (Wawancara Kasie Rehabilitasi, 10 Februari 2021).

Dalam hal sosialisasi program TAT beberapa dari anggota tim TAT dari BNNK Depok mengaku belum pernah mendapat sosialisasi secara formal dari pembina fungsi mengenai program TAT, namun mereka hanya mempelajari sendiri dari dokumen peraturan yang ada. "Untuk sosialisasi ke anggota tim, kendala utamanya adalah cepatnya perputaran rotasi anggota termasuk di BNNK Depok sendiri, anggota tim dari Kejaksaan Negeri Depok, ataupun anggota tim dari Satuan Narkoba Polresta Depok yang menaungi penanganan narkotika di Kota Depok. Sehingga dalam waktu satu tahun, bisa dua atau tiga kali perubahan pengajuan nama anggota tim TAT, karena jika ada satu orang yang berganti otomatis mengganti surat keputusan keanggotaan TAT yang ditandatangani oleh Kepala BNN Provinsi Jawa Barat. Selain itu transfer pengetahuannya juga butuh proses" (Wawancara Admin TAT, 10 Februari 2021).

Dari empat indikator efektivitas yaitu ketepatan sasaran program, sosialisasi program, tujuan program, dan pemantauan program, yang baru terpenuhi hanya ketepatan sasaran program. Namun untuk sosilisasi, pemenuhan tujuan program, dan pemantauan program belum optimal.

\section{b. Analisis Hambatan Program Tim Asesmen Terpadu}

Pelaksanaan asesmen terhadap penyalah guna narkotika bisa dimulai sejak tahap penyidikan. Penyidikan terhadap kasus tindak pidana narkotika dapat dilakukan oleh penyidik yang berasal dari instansi BNN ataupun kepolisian. Baik Penyidik BNN ataupun Penyidik Kepolisian memiliki wewenang yang sama dalam proses hukum (Muslikan \& Taufiq, 2019). Hambatan terhadap proses asesmen sering terjadi pada tahap penyidikan. Di Kota Depok sangat sedikit sekali pengajuan TAT oleh penyidik sesuai dengan waktu yang telah ditentukan.

Pasal 9 ayat (2) Peraturan bersama berbunyi "Tim Asesmen Terpadu sebagaimana dimaksud dalam pasal 8 ayat (1), memiliki kewenangan sebagai berikut:

1) Atas permintaan penyidik untuk melakukan analisis peran seseorang yang ditangkap atau tertangkap tangan sebagai korban penyalahgunaan Narkotika, pecandu narkotika, atau pengedar narkotika.

Menentukan kriteria tingkat keparahan pengguna narkotika sesuai dengan jenis kandungan yang dikonsumsi, situasi dan kondisi ketika ditangkap pada tempat kejadian perkara

2) Merekomendasikan rencana terapi dan rehabilitasi terhadap pecandu narkotika dan korban penyalahgunaan narkotika sebagaimana dimaksud pada huruf (b)“ 
(Pandjaitan, 2020) berpendapat bahwa frasa "atas permintaan penyidik" pada poin (a), membuat sejumlah celah yang menyebabkan tidak dilibatkannya Tim Asesmen Terpadu dalam sejumlah kasus narkotika. Karena tidak adanya kewajiban bagi Tim Asesmen Terpadu dalam melakukan asesmen dan memberikan rekomendasi kepada penegak hukum membuat tim ini menjadi tumpul dan pasif.

"Saat pengajuan permohonan TAT oleh penyidik beberapa berkas yang harus dilampirkan sebagai berikut: surat permohonan asesmen dari Polsek/Polres, surat perintah penyidikan, surat perintah tugas, surat perintah penangkapan, surat penahanan, surat perintah penyitaan, surat ketetapan status barang bukti sitaan narkotika, berita acara pemeriksaan, surat hasil pemeriksaan tes urine, kartu keluarga tersangka, KTP dan akte kelahiran tersangka. Pada umumnya tersangka yang dibawa untuk TAT oleh penyidik disangkakan dengan pasal 111 sd 114 dan pasal 127. Dalam pelaksanaan asemen terpadu sejauh ini tidak ada kendala mulai dari verifikasi data, asemen medis, asesmen hukum hingga pembahasan kasus (case conference). Semuanya sudah sesuai prosedur dan anggaran cukup, saat case conference biasanya hadir semua walaupun ada beberapa yang diwakilkan. Masalahnya ada pada sedikitnya pengajuan asesmen oleh penyidik. Alasan dari tim penyidik kepolisian karena rata-rata tersangka yang mereka tangkap terlibat jaringan atau terindikasi sebagai pengedar sehingga tidak bisa diajukan untuk TAT" (Wawancara Admin TAT, 21 Desember 2020).

Penulis melihat bahwa terdapat kendala minimnya waktu yang disediakan untuk menyelesaikan pengajuan permohonan TAT. Berdasarkan wawancara dengan penyidik BNN, pada tahap proses pengajuan permohonan asesmen, penyidik mengalami beberapa kendala yaitu mengenai waktu yang ditentukan maksimal 6 (enam) hari setelah penangkapan tersangka. Waktu 6 (enam) hari kurang cukup bagi penyidik karena masih harus melakukan pengambangan kasus. Selain itu juga untuk memeriksa barang bukti di Pusat Laboratorium Narkotika BNN juga membutuhkan waktu karena dibatasi kuota harian (Wawancara Penyidik BNN, 21 Desember 2020). Untuk itu diperlukan perumusan ulang terhadap regulasi mengenai batasan waktu untuk mengajukan permohonan TAT.

"Untuk TAT kita memang sedikit, namun penyidik dari kepolisian biasanya mengajukan permohonan asesmen medis atau dahulunya dikenal dengan Visum Et Repertum ke BNN dikarenakan oleh kasus P-19 yang merupakan pengembalian berkas oleh kejaksaan kepada penyidik untuk dilengkapi. Saat Jaksa meminta penyidik untuk melengkapi asesmen medis, barulah penyidik bersurat ke BNN. Namun asesmen medis tersebut tidak masuk ke dalam program TAT, karena sudah melewati batas waktu 6 hari, biasanya sekitar 20 hari setelah penangkapan, namun BNN hanya menyatakan bahwa orang tersebut pecandu atau bukan, mengenai keputusan akhir tetap pada vonis 
pengadilan" (Wawancara Kasie Rehabilitasi, 10 Februari 2021). Berdasarkan wawancara tersebut penulis menemukan masih ada opsi lain selain program TAT yaitu pelaksanaan asesmen medis yang menyatakan bahwa tersangka adalah seorang pecandu. Namun asesmen medis tersebut bukan sebagai bukti yang menguatkan atau suatu rekomendasi yang berkekuatan hukum seperti TAT yang sudah ada dalam peraturan bersama.

Dalam proses asemen hukum, tim hukum meninjau ulang terhadap asumsi yang ditetapkan penyidik terhadap tersangka apakah sebagai pengedar atau penyalahguna. Hal itu dapat dilihat dari jumlah barang buktinya dan tujuan penggunaannya. Jika barang buktinya sedikit dan penggunaannya hanya untuk konsumsi pribadi masuk kedalam kategori penyalahguna. Jika penggunaannya untuk dijual lagi, masuk kedalam kategori pengedar (Wawancara Perwakilan Tim Hukum, 21 Desember 2020).

Tim medis dalam melakukan asesmen medis menggunakan standar SEMA (Surat Edaran Mahkamah Agung) untuk menentukan seorang tersangka layak untuk direhabilitasi. Peran tim medis juga meninjau ulang sejauh mana tingkat kecanduan tersangka apakah dikategori ringan, sedang, atau berat sebagai dasar untuk mengeluarkan rekomendasi rehabilitasi. Namun keputusan rehabilitasi tetap ada dipengadilan (Wawancara Perwakilan Tim Dokter, 21 Desember 2020).

Setelah tim dokter dan tim hukum melakukan tugas nya untuk asesmen, lalu hasil asesmen dibawa ke pembahasan kasus (case conference). Dalam pembahasan kasus dihasilkan laporan tertulis mengenai rekomendasi TAT. Hasil rekomendasi TAT Kota Depok sejak tahun 2018 yang penulis teliti sudah sesuai prosedur dan sesuai tujuan dari terbentuknya TAT, semuanya mengarah pada saran agar tersangka yang merupakan pecandu narkotika dapat menjalani terapi rehabilitasi.

Menurut Kepala BNNK Depok "dalam tindak lanjut hasil rekomendasi Tim Asesmen Terpadu, kendala yang dihadapi ketika seorang tersangka diputuskan untuk mendapat hukuman pidana dan hukuman rehabilitasi adalah tidak tersedia fasilitas rehabilitasi di rutan. Di Depok tidak ada fasilitas rehabilitasi rawat inap milik pemerintah yang memungkinkan untuk merawat baik tersangka ataupun narapidana yang merupakan pecandu narkotika. Jika dititipkan di lembaga rehabilitasi seperti Marzuki Mahdi, RSKO, dan Balai Rehabilitasi BNN Lido harus ada yang bertanggungjawab terhadap pengawasan tersangka atau terdakwa" (Wawancara Kepala BNNK Depok, 21 Desember 2020).

Dalam mengatasi hambatan-hambatan TAT perlunya meninjau ulang regulasi yang sekiranya memberatkan pelaksanaan program terutama mengenai waktu maksimal pengajuan permohonan TAT oleh penyidik. Untuk mengoptimalkan pelaksanaan TAT juga diperlukan political willingness dari pihak-pihak pelaku kebijakan. Selain itu fasilitas rehabilitasi dan SDM rehabitasi 
perlu disediakan secara layak untuk mendukung tindak lanjut dari pelaksanaan TAT yang tujuannya agar tersangka yang juga pecandu narkotika mendapatkan haknya untuk rehabilitasi.

\section{Kesimpulan}

Pelaksanaan program Tim Asesmen Terpadu untuk wilayah Depok untuk tahun 2020 dapat dikatakan kurang efektif, karena realisasinya belum mencapai target yang dianggarkan. Terdapat beberapa kendala yaitu : 1) Pengajuan permohonan TAT oleh penyidik yang masih rendah sehingga menyebabkan pelaksanaan TAT belum mencapai target yang dianggarkan, 2) Proses pelaksanaan TAT bagi penyalahguna di lapangan belum merupakan sebuah kewajiban yang harus dilaksanakan oleh aparat penegak hukum, 3) Waktu maksimal pengajuan permohonan TAT dirasa kurang oleh penyidik.

Saran untuk ke depannya agar regulasi kebijakan Tim Asesmen Terpadu perlu masuk ke dalam peraturan per-Undang-Undangan seperti Peraturan Pemerintah (PP) sehingga pidana alternatif berupa rehabilitasi dapat dijalankan dengan optimal dan mengikat semua instansi terkait. Dalam rangka mendukung tindak lanjut dari program TAT agar tersangka yang merupakan pecandu narkotika mendapatkan pengobatan berupa rehabilitasi, diusulkan agar setiap kabupaten/kota memiliki tempat rehabilitasi yang memadai dimana terdapat penanganan dan pengawasan yang khusus terhadap tersangka atau narapidana narkotika yang perlu menjalani proses rehabilitasi berdasarkan hasil asesmen. 


\section{BIBLIOGRAFI}

Afrizal, Riki, \& Anggunsuri, Upita. (2019). Optimalisasi Proses Asesmen terhadap Penyalah Guna Narkotika dalam Rangka Efektivitas Rehabilitasi Medis dan Sosial Bagi Pecandu Narkotika. Jurnal Penelitian Hukum De Jure, 19(3), 259-268.

Agustino, Leo. (2016). Dasar-dasar kebijakan publik (Edisi Revisi). Bandung: Alfabeta.

Dunn, William N. (2003). Pengantar analisis kebijakan publik Edisi Kedua. Yogyakarta: Gajah Mada University.

Hidayat, Rusman, \& Heryanto. (2019). the Effect of Motivation and Compensation on Employee Performance With Work Satisfaction As Intervening (Case Study in the Technical Department of Pt Semen Padang). Archives of Business Research, 7(11), 78-90. https://doi.org/10.14738/abr.711.6892

Huda, Nurul, Saefuddin, Yusuf, Gumira, Seno Wibowo, \& Sumarji, Sumarji. (2020). Asesmen Terpadu: Penerapan Restorative Justice Penanggulangan Kejahatan Narkotika Di Indonesia. Jurnal Ilmiah Kebijakan Hukum, 14(1), 111-124.

Iskandar, Anang, \& IK, S. (2019). Penegakan Hukum Narkotika (Rehabilitatif terhadap Penyalah Guna dan Pecandu, Represif terhadap Pengedar). Jakarta: Elex Media Komputindo.

Kawengian, Debby D. V, \& Rares, Joyce Jacinta. (2015). Evaluasi Kebijakan Pencegahan dan Pemberantasan Perdagangan Manusia (Trafficking) Terutama Perempuan dan Anak di Kabupaten Minahasa Selatan Provinsi Sulawesi Utara. Acta Diurna KomunikasI, 4(5).

Miles, Matthew B., \& Huberman, A. Micheael. (2007). Analisis data Kualitatif (Tjetjep Rohedi, Pentj). Jakarta: UI Press.

Muslikan, Muslikan, \& Taufiq, Muhammad. (2019). Pelaksanaan Assesmen Tentang Rehabilitasi Terhadap Korban Penyalahgunaan Narkotika Ditinjau Dari Peraturan Perundang-Undangan. Jurnal Ilmiah Living Law, 11(1), 61-80.

Pandjaitan, Hinca IP. (2020). BNN Bubar atau Sangar. Jakarta: RMbooks.

Pertiwi, Monica, \& Nurcahyanto, Herbasuki. (2017). Efektivitas Program Bpjs Kesehatan Di Kota Semarang (Studi Kasus Pada Pasien Pengguna Jasa Bpjs Kesehatan Di Puskesmas Srondol). Journal of Public Policy and Management Review, 6(2), 416-430.

Supratman, Dindin, Nugroho, Purwoko, \& Wijayanti, Retno Dewi. (2020). Asesmen Terpadu Dalam Rangka Mendukung Kebijakan Rehabilitasi Penyalah Guna Narkoba. Jurnal Litbang Sukowati: Media Penelitian Dan Pengembangan, 3(2), 13. 